\title{
PENINGKATAN PRODUKTIVITAS KERJA MELALUI PENERAPAN PROGRAM K3 DI LINGKUNGAN KONSTRUKSI
}

\author{
Nur Aini Faridah Rahmawati ${ }^{1)}$, Martono ${ }^{1)}$, Sugiharto ${ }^{1)}$, Karnawan Joko Setyono ${ }^{\text {1) }}$, Parhadi ${ }^{\text {1) }}$ \\ 1) Jurusan Teknik Sipil Politeknik Negeri Semarang \\ Jln. Prof. Soedarto, SH, Tembalang, Semarang, 50275 \\ Email: martono@polines.ac.id, sugiharto@polines.ac.id
}

\begin{abstract}
ABSTRAK
Penerapan Keselamatan dan Kesehatan Kerja (K3) merupakan salah satu bentuk upaya untuk menciptakan lingkungan kerja yang aman dan sehat serta untuk mencegah kemungkinan terjadinya kecelakaan dan penyakit yang disebabkan oleh pekerjaan dan lingkungan kerja. Faktor utama yang menjadi tulang punggung suatu pekerjaan adalah manusia, dalam hal ini adalah para pekerja. Dengan adanya penerapan program Keselamatan dan Kesehatan Kerja untuk mengubah pola pikir para pekerja dan membangkitkan kesadaran dari dalam diri para pekerja bahwa pentingnya Keselamatan dan Kesehatan Kerja (K3). Maka dari itu mengingat bahwa adanya bahaya potensi risiko kerja di bidang jasa konstruksi maka masyarakat supaya untuk senantiasa menerapkan program Keselamatan dan Kesehatan Kerja yang akan berpotensi untuk meningkatkan Produktivitas kerja bagi para pekerja. Penerapan program K3 yang di lakukan oleh PT. Sinar Cerah Sempurna Semarang dalam pembangunan gedung penunjang pelayanan RSUP Dr.Kariadi antara lain dimulai dari Project Safety Review, Safety Inspection, Pemasangan rambu-rambu proyek, Safety morning, Kelengkapan Alat Pelindung Diri, Pemasangan Safety Nett, Pemasangan Safety Line, Pemasangan lampu penerangan hingga Kebersihan Area proyek. Kegiatan Penerapan Program K3 ini bertujuan untuk meningkatkan produktivitas dan kualitas bagi para pekerja dibidang konstruksi.
\end{abstract}

Kata kunci: keselamatan dan kesehatan kerja (k3), program k3, produktivitas kerja.

\section{PENDAHULUAN}

\section{Latar Belakang}

Permasalahan para pekerja di Indonesia mengenai Keselamatan dan Kesehatan kerja masih sangat terabaikan, sehingga dapat menimbulkan angka kecelakaan kerja yang signifikan. Sedangkan perusahaan jasa konstruksi tidak dapat terlepas dari tenaga kerja, karena tenaga kerja adalah faktor penting bagi perusahaan. Maka dari itu mengingat ancaman bahaya potensial dari kecelakaan kerja tersebut maka Pemerintah telah menetapkan kebijakan tenaga kerja terhadap aspek Keselamatan dan
Kesehatan Kerja (K3) melalui peraturan perundangan. Peraturan perundangan keselamatan dan kesehatan kerja (K3) merupakan salah satu upaya dalam pencegahan kecelakaan kerja, penyakit akibat kerja, peledakan, kebakaran, dan pencemaran lingkungan kerja yang penerapannya menurut jenis dan sifat atau kegiatan pekerjaan serta kondisi lingkungan kerja. Menurut data Indonesia dalam Ramli (2010:28) pada tahun 2007 terjadi 89000 kecelakaan kerja di seluruh perusahaan yang menjadi anggota jamsostek yang meliputi 7 juta pekerja. Jika jumlah pekerja di Indonesia mencapai 90 juta orang maka jumlah kecelakaan diperkirakan 
lebih dari 700.000 kejadian setiap tahun. Karena itu, ILO memperkirakan kerugian akibat kecelakaan kerja mencapai 2-4\% dari GNP suatu Negara. Kerugian akibat kecelakaan kecelakaan dan kejadian lainnya ini merupakan risiko yang harus dihadapi oleh setiap organisasi dan atau peruahaan. Menurut Siregar (2005:1) faktor manusia sebagai unsur penyebab utama kecelakaan kerja menurut catatan adalah $85 \%$ (ILO, Pencegahan kecelakaan kerja) dan $15 \%$ merupakan faktor kondisi yang berbahaya. Oleh karena itu kecelakaan kerja banyak disebabkan oleh faktor manusia. Sehingga, melalui permasalahan hal ini maka perlu adanya Penerapan Keselamatan dan Kesehatan Kerja (K3) yang merupakan salah satu bentuk upaya untuk menciptakan lingkungan kerja yang aman, sehat, bebas dari pencemaran lingkungan serta untuk mencegah kemungkinan tejadinya kecelakaan kerja dan penyakit yang disebabkan oleh pekerjaan dan lingkungan kerja yang pada akhirnya dapat meningkatkan sistem dan produktifitas para pekerja. Dengan adanya penerapan program Keselamatan dan Kesehatan Kerja untuk mengubah pola pikir para pekerja dan membangkitkan kesadaran dari dalam diri para pekerja bahwa pentingnya Keselatan dan Kesehatan Kerja (K3). Maka dari itu mengingat bahwa adanya bahaya potensi risiko kerja di bidang jasa konstruksi maka masyarakat supaya untuk senantiasa menerapkan program Keselamatan dan Kesehatan Kerja yang akan berpotensi untuk meningkatkan Produktivitas kerja bagi para pekerja.

Salah satunya perusahaan yang menerapkan prinsip dan program
Keselamatan dan Kesehatan kerja (K3) merupakan PT. Sinar Cerah Sempurna Semarang dalam Pembangunan Proyek RSUP Dr.Kariadi Kota Semarang. Berdasarkan penelitian dan observasi lapangan di proyek Rumah Sakit Umum Pusat Dr. Kariadi Semarang permasalahan yang menjadi prioritas untuk menyelesaikan tinjauan/ penelitian tentang Keselamatan dan Kesehatan Kerja yaitu menerapkan kebijakan program Keselamatan dan Kesehatan Kerja bagi para pekerja yang pada akhirnya dapat meningkatkan produktivitas kerja di lingkungan konstruksi.

\section{Tujuan Penelitian}

Tujuan dari penelitian ini adalah: a) Untuk mengetahui apakah proyek Pembangunan Gedung Penunjang Pelayanan RSUP Dr. Kariadi telah menerapkan sistem K3; b) Untuk mengetahui apakah proyek Pembangunan Gedung RSUP Dr. Kariadi telah menerapkan program K3 di lingkungan konstruksi; c) Untuk mengetahui bagaimana penerapan program K3 konstruksi yang dilakukan pada proyek Pembangunan Gedung Penunjang Pelayan RSUP Dr. Kariadi; d) Untuk mengetahui peningkatan produktivitas kerja melalui penerapan program $\mathrm{K} 3$ di lingkungan konstruksi.

\section{Manfaat Penelitian}

Adapun manfaat dari penelitian ini adalah: a) Dengan adanya informasi ini maka dapat digunakan untuk mengurangi terjadinya kecelakaan kerja di lingkungan konstruksi; b) Untuk menciptakan suasana atau kondisi lingkungan kerja yang baik, sehat, nyaman, aman dan bebas dari pencemaran lingkungan; c) 
Untuk mencegah dan mengindari adanya risiko penyakit dan kecelakaan kerja.

Untuk meningkatkan produktivitas kerja melalui penerapan program Keamanan, Kesehatan dan Keselamatan Kerja (K3) di lingkungan konstruksi.

\section{TINJAUAN PUSTAKA}

\section{Pengertian Keselamatan dan Kesehatan Kerja}

Keamanan, Kesehatan dan Keselamatan Kerja (K3) merupakan singkatan dari Keselamatan dan Kesehatan Kerja. K3 adalah suatu ilmu pengetahuan dan penerapan guna mencegah kemungkinan terjadinya kecelakaan dan penyakit yang disebabkan oleh pekerjaan dan lingkungan kerja. Menurut America Society of Safety and Engineers (2015) K3 diartikan sebagai bidang kegiatan yang ditujukan untuk mencegah semua jenis kecelakaan yang ada kaitannya dengan lingkungan dan situasi kerja. Secara umum keselamatan kerja dapat dikatakan sebagai ilmu dan penerapannya yang berkaitan dengan mesin, pesawat, alat kerja, bahan dan proses pengolahannya, landasan tempat kerja dan lingkungan kerja serta cara melakukan pekerjaan guna menjamin keselamatan tenaga kerja dan aset perusahaan agar terhindar dari kecelakaan dan kerugian lainnya. Keselamatan kerja juga meliputi penyediaan APD, perawatan mesin dan pengaturan jam kerja yang manusiawi.

Dalam K3 juga dikenal istilah Kesehatan Kerja, yaitu: suatu ilmu yang penerapannya untuk meningkatkan kulitas hidup tenaga kerja melalui peningkatan kesehatan, pencegahan Penyakit Akibat Kerja meliputi pemeriksaan kesehatan, pengobatan dan pemberian makan dan minum bergizi. Istilah lainnya adalah Ergonomy yang merupakan keilmuan dan aplikasinya dalam hal sistem dan desain kerja, keserasian manusia dan pekerjaannya, pencegahan kelelahan guna tercapainya pelakasanaan pekerjaan secara baik. Dalam pelaksanaannya K3 adalah salah satu bentuk upaya untuk menciptakan tempat kerja yang aman, sehat dan bebas dari pencemaran lingkungan, sehingga dapat mengurangi dan atau bebas dari kecelakaan yang pada akhirnya dapat meningkatkan sistem dan produktifitas kerja.

Menurut Winda Purnama Tagueha (2018) Pelaksana K3 sebagai pihak yang bertanggungjawab selama proses pembangunan harus mendukung dan mengupayakan program-program yang dapat menjamin agar dapat meminimalisir bahkan menghilangkan kecelakaan kerja. Hubungan antara pihak yang berkewajiban memperhatikan masalah kselamatan dan kesehatan kerja adalah kontrakstor dengan pekerja. Kewjiban kontraktor dan rekan kerjanya adalah pekerjanya selama masa pembangunan berlangsung. Pada rentang waktu pelaksanaan pembangunan, kontraktor sudah selayaknya tidak mengizinkan pekerjanya untuk beraktivitas apabila terjadi hal-hal sebagai berikut: a) Tidak mematuhi peraturan keselamatan dan kesehatan kerja; b) Tidak menggunakan peralatan pelindung diri selama bekerja; c) Mengizinkan para pekerja menggunakan peralatan yang tidak aman. 


\section{Kesehatan Kerja}

Kesehatan kerja adalah suatu keadaan atau kondisi badan/tubuh yang terlindungi dari segala macam penyakit atau gangguan yang diakibatkan oleh pekerjaan yang dilaksanakan. Dalam dunia pekerjaan segala kendala kerja harus harus dihindari, sementara produktivitas yang optimal merupakan keinginan setiap pengusaha konstruksi, dengan demikian sasaran keuntungan akan dapat dicapai. Salah satu kendala dalam proses kerja adalah penyakit kerja. Penyakit kerja membawa dampak kerugian bagi perusahaan berupa pengurangan waktu kerja dan biaya untuk mengatasi penyakit kerja tersebut. Sehingga bagi pengusaha konstruksi, pencegahan jauh lebih menguntungkan dari pada penanggulangannya. Dengan melihat pengertian masing-masing dari keselamatan kerja, maka keselamatan dan kesehatan kerja dapat diartikan sebagai kondisi dan factor-faktor yang berdampak pada kesehatan karyawan, pekerja kontrak, porsenil kontraktor, tamu dan orang lain di tempat kerja (Balandatu, 2000).

\section{Kecelakaan Kerja}

Menurut M. Sulaksmono (1997) kecelakaan adalah suatu kejadian yang tidak diduga dan tidak dikehhendaki yang mengacaukan suatu aktifitas yang telah diatur. Tidak terduga oleh karena latar belakang peristiwa itu tidak terdapat adanya unsur kesengajaan, terlebih dalam bentuk perencanaan. Peritiwa kecelakaan disertai kerugian material ataupun penderitaan dari yang paling ringan sampai pada yang paling berat.

Kecelakaan akibat kerja adalah kecelakaan yang ada hubungannya dengan pekerjaan, bahwa kecelakaan terjadi dikarenakan oleh pekerjaan atau pada waktu melaksanakan pekerjaan. Termasuk kecelakaan yang terjadi dalam perjalanan dari rumah menuju tempat kerja ataupun sebaliknya. Maka dalam hal ini terdapat dua permasalahan penting, yaitu: a) Kecelakaan adalah akibat langsung dari pekerjaan; atau b) Kecelakaan terjadi pada saat pekerjaan sedang dilakukan.

\section{Perlindungan Tenaga Kerja}

Perlindungan tenaga kerja meliputi aspek-aspek yang cukup luas, yaitu perlindungan dari segi fisik yang mencakup perlindungan keselamatan dari kecelakaan kerja dan kesehatanya serta adanya pemeliharaan moril kerja dan perlakuan yang sesuai dengan martabat manusia dan moral agama. Setiap tenaga kerja mempunyai hak untuk perlindungan atas: a) Keselamatan dan kesehatan kerja; b) Moral dan kesusilaan; c) Perlakuan yang sesuai dengan harkat dengan martabat serta nilai nilai agama.

\section{Perlindungan}

tersebut dimaksudkan agar tenaga kerja dapat merasa aman dapat melakukan pekerjaan sehari-hari. Sehingga dapat meningkatkan produksi dan produktivitas pekerjaannya. Tenaga kerja harus memperoleh perlindungan dari berbagai peristiwa disekitarnya dan pada dirinya yang dapat menimpa dan mengganggu dalam pelaksanaan.

\section{Alat Pelindung Diri}

Alat pelindung diri adalah kelengkapan yang wajib digunakan saat bekerja sesuai bahaya dan risiko kerja untuk menjaga keselamatan pekerja itu sendiri dan orang di 
sekelilingnya. Kewajiban itu sudah disepakati oleh pemerintah melalui Departemen Tenaga Kerja Republik Indonesia. Dalam bidang konstruksi ada beberapa peralatan yang digunakan untuk melindungi seseorang dari kecelakaan ataupun bahaya yang mungkin bisa terjadi dalam proyek konstruksi. Peralatan ini wajib digunakan oleh seseorang yang bekerja dalam suatu lingkungan proyek konstruksi. Dalam penggunaan alat pelindung diri, haruslah mempertimbangkan faktorfaktor sebagai berikut: a) Enak dan nyaman dipakai; b) Tidak mengganggu ketegangan kerja dan tidak membatasi ruang untuk bekerja; c) Memberikan perlindungan yang efektif terhadap segala jenis bahaya; d) Memenuhi syarat estetika; e) Memperhatikan efek samping penggunaan alat pelindung diri; f) Mudah dalam pemeliharaan, tepat ukuran, tepat penyediaan, dan harga yang terjangkau.

Kesehatan dan Keselamatan Kerja adalah dua hal yang sangat penting. Oleh karena itu, semua perusahaan kontraktor berkewajiban menyediakan semua keperluan peralatan/ perlengkapan perlindungan diri atau Personal Protective Equipment (Ervianto, 2005:hal 99).

Beberapa bentuk dari peralatan perlindungan diri telah memiliki standar di proyek konstuksi dan tersedia di pabrik ataupun industri konstruksi. Helm pelindung dan sepatu merupakan peralatan perlindugan diri yang secara umum digunakan para pekerja untuk melindungi diri dari benda keras. Di beberapa industri, kacamata pelindung sangatlah dibutuhkan. Kelengkapan peralatan perlindungan diri membantu pekerja melindungi dari kecelakaan dan luka-luka (Charles A. W,1999, hal 401).

Beberapa $\begin{gathered}\text { faktor } \\ \text { yang } \\ \text { mempengaruhi pekja } \\ \text { menggan }\end{gathered}$
diri antara lainnya: a) Sulit, tidak
nyaman, atau mengganggu untuk
digunakan. b) Pengertian yang lebih
rendah akan pentingnya peralatan
keamanan. c) Ketidakdisiplinan
dalam peggunaan (Charles A, W,
1999, hal 403).

\section{Tujuan Keselamatan dan Kesehatan Kerja}

Beberapa pendapat para ahli tentang tujuan dari keselamatan dan kesehatan kerja antara lain adalah : Menurut Suma'mur (1989), tujuan dari keselamatan dan kesehatan kerja adalah: a) Melindungi tenaga kerja atas hak dan keselamatannya dalam melakukan pekerjaannya untuk kesejahteraan hidup dan meningkatkan kinerja. b) Menjamin Keselamatan kerja orang lain yang berada di tempat kerja. c) Sumber produksi dipelihara dan digunakan secara aman dan efisien.

Tujuan Keselamatan dan Kesehatan Kerja dalam Peraturan Pemerintah Nomor 50 Tahun 2012 tentang Sistem Manajemen Keselamatan dan Kesehatan Kerja tercermin dalam Tujuan Penerapan SMK3 dalam Pasal 2: a) Meningkatkan efektifitas perlindungan keselamatan dan kesehatan kerja yang terencana, terukur, terstruktur, dan terintegrasi. b) Mencegah dan mengurangi kecelakaan kerja dan penyakit akibat kerja dengan melibatkan unsur manajemen, pekerja/buruh, dan/atau serikat pekerja/serikat buruh; serta. c) 
Menciptakan tempat kerja yang aman, nyaman, dan efisien untuk mendorong produktivitas.

Selain menurut PP 50 tahun 2012, tujuan Keselamatan dan Kesehatan Kerja juga dibahas oleh Djamaluddin Ramlan tahun 2006 dalam bukunya "Dasar-dasar kesehatan kerja". Djamaluddin Ramlan (2006) membahas tujuan Keselamatan dan Kesehatan Kerja dengan membaginya dalam 3 bagian.

Tujuan kesehatan kerja menurut Djamaluddin Ramlan (2006) adalah: a) Memelihara dan meningkatkan derajat kesehatan masyarakat pekerja disemua lapangan pekerjaan ketingkat yang setinggi-tingginya baik fisik, mental maupun kesejahteraan social; b) Mencegah timbulnya gangguan kesehatan masyarakat pekerja yang diakibatkan oleh keadaan/kondisi lingkungan kerjanya seperti kecelakaan akibat kerja; c) Memberi perlindungan bagi pekerja saat melaksanakan pekerjaannya dan kemungkinan terjadinya bahaya yang disebabkan oleh faktor-faktor yang membahayakan kesehatan di tempat kerja; d) Menempatkan pekerja disuatu lingkungan pekerjaan berdasarkan keterampilan, kemampuan fisik dan psikis pekerjaannya.

\section{Peran penting program K3 dalam meningkatkan produktivitas kerja}

Sejumlah kasus kecelakaan yang terjadi di tempat kerja bukan menjadi rahasia umum lagi. Penyebab terjadinya kecelakaan di tempat kerja diakibatkan karena adanya keterbatasan fasilitas keselamatan kerja dan adanya kelemahan pemahaman faktor keselamatan yang mesti ditetapkan perusahaan.
Pemeliharaan keselamatan dan kesehatan kerja (K3) para karyawan adalah hal yang sangat penting untuk diperhatikan oleh setiap perusahaan. Tujuan memperhatikan hal ini yaitu untuk mengurangi ataupun menghilangkan risiko kecelakaan kerja yang dialami oleh para karyawan guna mencapai keamanan dan kenyamanan kerja dalam meraih tujuan perusahaan secara efisien dan efektif.

Berdasarkan peraturan Menteri Tenaga Kerja nomor Per.05/Men/1996 pasal 2, sebagai tujuan serta sasaran sistem manajemen keselamatan dan kesehatan kerja ialah menciptakan suatu sistem keselamatan dan kesehatan kerja di tempat kerja dengan melibatkan unsur manajemen, tenaga kerja, kondisi dan lingkungan kerja yang terintegrasi dalam rangka mencegah dan mengurangi kecelakaan dan penyakit akibat kerja serta terciptanya tempat kerja yang aman, efisien, dan produktif.

Diciptakannya peraturan dan undang-undang mengenai sistem manajemen keselamatan dan kesehatan kerja diharapkan akan memberikan manfaat yang besar untuk masyarakat umum, khususnya untuk para pekerja itu sendiri. Tidak hanya itu saja, penerapan sistem manajemen keselamatan dan kesehatan kerja pun mempunyai manfaat yang besar untuk perusahaan yaitu perusahaan tidak akan dirugikan dalam hal kegiatan produksi karena hilangnya sebagian waktu, kerugian material, serta biaya pengobatan akibat kecelakaan dalam bekerja. Secara moral, pekerja akan merasa aman serta nyaman dalam bekerja, 
sehingga produktivitasnya dalam bekerja pun akan meningkat.

Salah satu upaya menjaga keselamatan dan kesehatan kerja para karyawan yaitu dengan menyediakan APD sesuai standar.

Alat Pelindung Diri merupakan kelengkapan yang wajib dipakai ketika bekerja seusai dengan bahaya serta risiko kerja guna menjaga keselamatan pekerja itu sendiri serta orang yang berada di sekelilingnya.

\section{METODE PENELITIAN}

\section{Tempat dan Waktu Penelitian}

Penelitian ini dilakukan pada proyek Pembangunan Gedung Pelayanan RSUP Dr. Kariadi Semarang. Pemilik proyek adalah PT. SINAR CERAH SEMPURNA Semarang. Penelitian ini dilakukan selama satu setengah bulan mulai dari persiapan, survey lapangan, analisis data sampai penulisan hasil penelitian dan peyusunan laporan.

\section{Teknik Pengumpulan Data}

Adapun teknik pengumpulan data penelitian ini adalah dengan cara: : a) Wawancara langsung dengan pihak K3 yang ada di Proyek Pembangunan Gedung Pelayanan RSUP Dr. Kariadi Semarang. b) Survey dan penelitian langsung di proyek RSUP Dr. Kariadi Semarang.

\section{Metode Analisis Data}

Setiap peristiwa sangat mungkin untuk dianalisis khususnya menganalisis penerapan program Keselamatan dan Kesehatan Kerja yang pada akhirnya dapat meningkatkan produktivitas dan kualitas para pekerja dan sebagai perbandingan. Kemudian dari data yang diperoleh maka penulis dapat menyusun tabel tentang Pelaksanaan K3 yang berada di Lapangan. Kemudian dapat diketahui Produktivitas Kerja para pekerja melalui Penerapan Program K3.

\section{HASIL DAN PEMBAHASAN}

Penerapan Program K3 di proyek Pembangunan Gedung Pelayanan RSUP Dr. Kariadi antara lain:

\section{Pemasangan Rambu - Rambu Proyek}

Rambu-rambu keselamatan dan kesehatan kerja merupakan tandatanda yang dipasang ditempat kerja/proyek, guna mengingatkan atau mengidentifikasi pada semua pelaksana kegiatan di sekeliling tempat tersebut terhadap kondisi, risiko, yang terkait dengan keselamatan dan kesehatan kerja masing-masing.

Manfaat pemasangan ramburambu proyek: a) Menyediakan kejelasan informasi dan memberikan pengarahan umum; b) Memberikan penjelasan tentang kesehatan dan keselamatan kerja; c) Menunjukkan adanya potensi bahaya yang mungkin tidak terlihat; d) Mengingatkan para pelaksanan dimana harus menggunakan peralatan perlindungan diri sebelum memulai aktifitas di tempat kerja; e) Menunjukkan dimana peralatan darurat keselamatan berada; f) Memberikan peringatan waspada terhadap beberapa tindakan yang atau perilaku yang tidak diperbolehkan. 


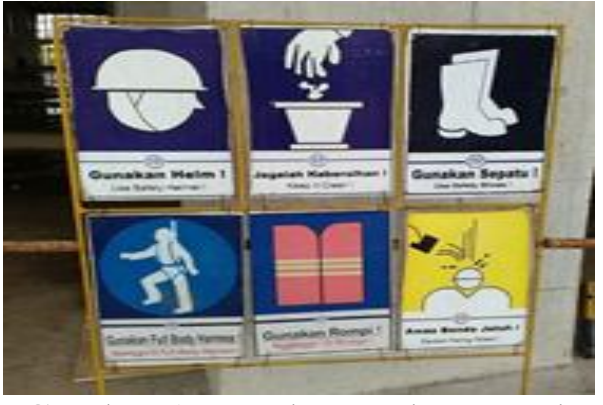

Gambar 1. Rambu-rambu proyek RSUP Dr. Kariadi

\section{Briefing Sebelum Kerja / Safety Morning}

Briefing adalah sebuah pendekatan komunikasi antar-muka (face to face) yang secara rutin dilakukan dalam organisasi agar seluruh anggota tim kerja memiliki kesamaan persepsi, sikap dan tindakan yang produktif terhadap pencapaian tujuan organisasi.

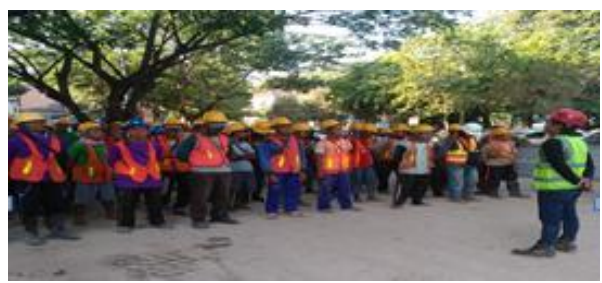

Gambar 2. Safety Morning

\section{Pemakaian Alat Pelindung Diri yang lengkap}

Alat pelindung diri (APD) adalah suatu kewajiban dimana biasanya para pekerja atau buruh bangunan yang bekerja disebuah proyek atau pembangunan sebuah gedung,diwajibkan menggunakannya. Alat-alat demikian harus memenuhi persyaratan tidak mengganggu kerja dan memberikan perlindungan efektif terhadap jenis bahaya. Alat Pelindung Diri yang disediakan oleh pengusaha dan dipakai oleh tenaga kerja harus memenuhi syarat pembuatan, pengujian dan sertifikat. Alat Pelindung diri berperan penting terhadap Kesehatan dan Keselamatan Kerja, serta berguna untuk mencegah pekerja dari kecelakaan seperti: Tertimpa benda keras dan berat, tertusuk atau terpotong benda tajam, terjatuh dari tempat tinggi, terbakar atau terkena aliran listrik, terkena zat kimia berbahaya pada kulit atau melalui pernafasan, pendengaran menjadi rusak karena suara kebisingan, penglihatan menjadi rusak diakibatkan intensitas cahaya yang tinggi, terkena radiasi dan gangguan lainnya. Macam alat pelindung diri antara lain adalah: Masker alat pelindung hidung, topi pengaman, sarung tangan, sepatu pengaman sebagai alat pelindung kaki, pakaian kerja, tali pengaman untuk melindungi pekerja dari kemungkinan jatuh.

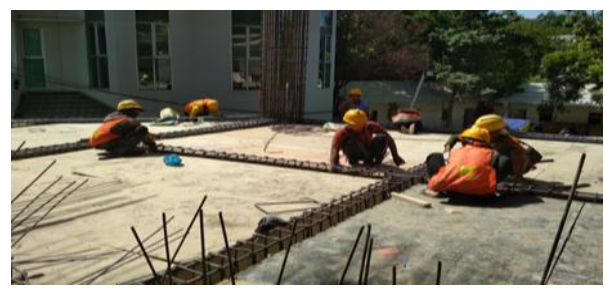

Gambar 3. Pemakaian APD Lengkap

\section{Pemasangan Jaring-Jaring (Safety Nett)}

Jaring Pengaman Bangunan atau yang umum disebut dengan Jaring-Jaring proyek yang digunakan untuk mengamankan konstruksi satu bangunan yang disebut pengamanan dari kejatuhan bakal puing-puing bangunan yang mungkin saja saja bisa berlangsung sepanjang sistem pembangunan berjalan. Jaring pengaman bangunan juga umum dipakai untuk keselamatan beberapa pekerja konstruksi dari jatuh dari ketinggian, kadang-kadang karenanya ada jaring safety, beberapa pekerja bakal terasa lebih aman untuk bekerja di atas ketinggian dengan memprioritaskan keselamatan. 


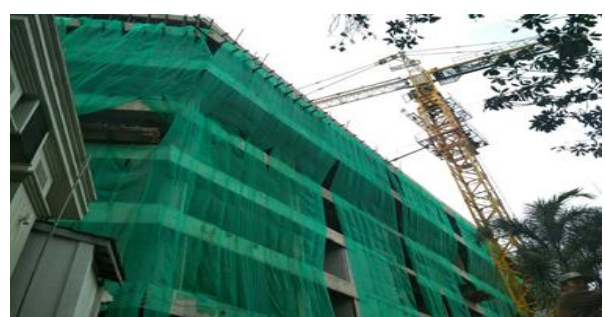

Gambar 4. Pemasangan Jaring-jaring (Safety Nett)

\section{Pemasangan Safety Line}

Safety Line digunakan dalam zona konstruksi untuk memberitahu orang-orang tentang pembangunan berkelanjutan dan bahwa ada kemungkinan bahaya dalam wilayah batas-batasnya. Pita konstruksi biasanya menggunakan kombinasi warna kuning-hitam dan menggabungkan dicetak teks, seperti "Under Construction", "Perhatian", "Zona Kerja", dan "Keep Out".

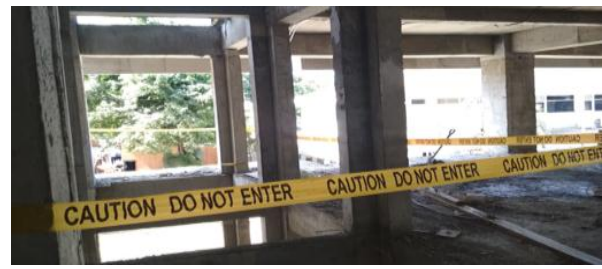

Gambar 5. Pemasangan SafetyLine

Tujuan Pemasangan Safety Line: a) Memberikan peringatan bahwa ada area tempat berbahaya; b) Menutup suatu area agar tidak ada yangleintasi area tersebut selain petugas yang berwenang; c) Memberikan informasi bahwa sedang ada pmbangunan berkelanjutan.

\section{Pemasangan Lampu Penerangan}

Untuk mencegah atau mengurangi potensi kerugian dari penerangan yang buruk, maka penerangan di tempat kerja harus memenuhi syarat untuk melakukan pekerjaan, khususnya di bidang konstruksi. Penerangan yang baik dan sesuai sangat penting untuk peningkatan kualitas dan produktivitas.

Dalam jurnal ILO yang berjudul "Improving Working Condition and Productivity in the Garment Industry", menunjukkan bahwa perbaikan penerangan di tempat kerja dapat meningkatkan produktivitas (10\%) dan pengurangan kesalahan kerja (30\%).

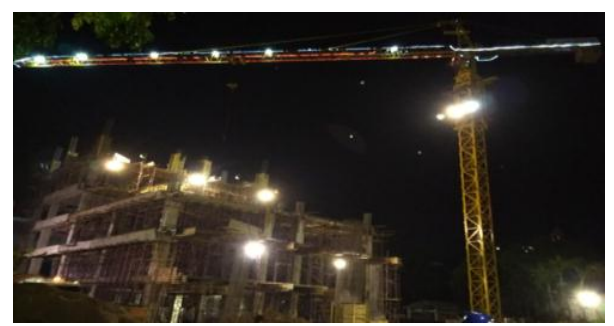

Gambar 6. Pemasangan Lampu Penerangan

\section{Kebersihan Area Proyek}

Kondisi proyek yang bersih bisa memberikan banyak efek positif dalam proses pelaksanaan pekerjaan. Dari mulai kinerja tukang yang maksimal karena merasakan nyaman dalam bekerja, kualitas pekerjaan juga terjaga karena tukang bisa fokus mengerjakan pekerjaan tanpa gangguan lingkungan yang kotor. Begitu juga dalam bidang safety dan keamanan.

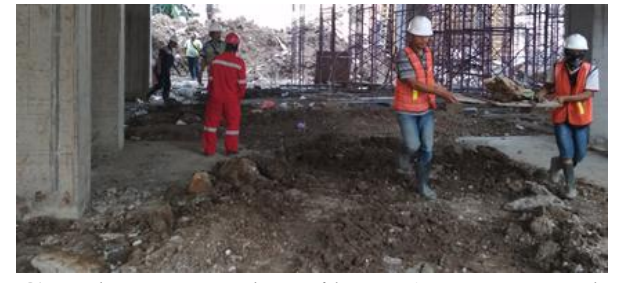

Gambar 7. Kebersihan Area Proyek

Kegiatan pembersihan termasuk dalam kegiatan inspeksi, karena pada saat melakukan kegiatan kebersihan berarti melakukan pengontrolan terhadap barang-barang yang tidak 
dipergunakan di tempat kerja. Tujuan jangka panjang dari kegiatan ini adalah meminimalkan terjadinya kesalahan-kesalahan kecil yang bisa mengganggu proses produksi, sehingga kualitas produk yang dihasilkan tetap terjaga.

\section{Statistik Kecelakaan Kerja di Indonesia dari Tahun 2007 - 2012}

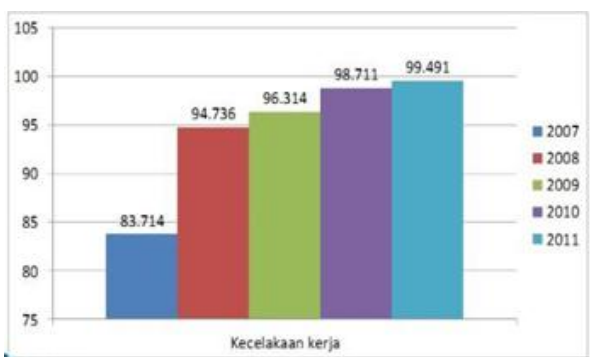

Gambar 8. Diagram statistik kecelakaan kerja di Indonesia

Menurut Dwi Handoko (2014) dalam artikel "Pengaruh Keselamatan dan Kesehatan Kerja Pada Bangunan Pekerjaan Gedung dan Penataan Ruang". Jurnal Konstruksia. Volume 2 no $\mathrm{V}$.

Berdasarkan data grafik dari tahun 2007-2011 terjadi peningkatan kecelakaan kerja di Indonesia setiap tahunnya. Dari tahun 2007 sejumlah 83.714 orang, tahun 2008 sejumlah 94.736 orang, tahun 2009. sejumlah 96.314 orang, tahun 2010 sejumlah 98.711 orang, tahun 2011 sejumlah 99.491 orang (Anas Yustiawan dalam Dwi handoko (2014).

Menurut teori efek domino H.W Heinrich (1931) juga bahwa kontribusi terbesar penyebab kasus kecelakaan kerja adalah berasal dari faktor kelalaian manusia yaitu sebesar $88 \%$. Sedangkan $10 \%$ lainnya adalah dari faktor ketidaklayakan property/asset/barang dan $2 \%$ faktor lainnya.
Hasil evaluasi kejadiankejadian kecelakaan kerja selama ini dapat disimpulkan beberapa faktor penyebab terjadi kecelakaan baik yang telah menimbulkan korban jiwa maupun luka-luka yang disebabkan tidak dilibatkan ahli teknik konstruksi, penggunaan metoda pelaksanaan yang tepat, lemahnya pengawasan pelaksanaan konstruksi di lapangan, belum sepenuhnya melaksanakan peraturan-peraturan menyangkut $\mathrm{K} 3$ yang telah ada, lemahnya pengawasan penyelenggaraan K3, kurang memadainya baik dalam kualitas dan kuantitas ketersediaan ketersediaan Alat Pelindung Diri (APD), Faktor lingkungan sosial ekonomi dan budaya pekerja dan kurang disiplinnya para tenaga kerja didalam mematuhi ketentuan mengenai $\mathrm{K} 3$, antara lain Pemakaian APD kecelakaan kerja (Badan Pembinaan Konstruksi dan Sumber Daya Manusia, 2007).

\section{Desain Penelitian}

Jenis penelitian yang digunakan adalah penelitian pengembangan $\mathrm{RnD}$ Penelitian pengembangan digunakan untuk mendesain produk atau prosedur baru yang teruji secara sistematis di lapangan, dievaluasi, dikembangkan sedemikian sehingga memenuhi kriteria efektivitas, kualitas atau kemiripan dengan suatu standar (Borg dan Gall, 1983). Model pengembangan yang digunakan dalam penelitian ini adalah model yang dikembangkan oleh Sukmadinata (Syaodih 2007:182). Model ini meliputi 2 tahap pengembangan yaitu studi pendahuluan dan pengembangan bahan ajar. 


\section{Teknik Pengumpulan Data}

Dalam penelitian ini digunakan teknik sebagai berikut: a) Wawancara dilakukan dua kali. Wawancara pertama yang dilakukan sebelum penelitian dimulai bertujuan untuk mengungkap faktor-faktor pendukung pembelajaran dan wawancara kedua dilakukan terhadap seorang subyek dalam penelitian uji coba terbatas untuk mengungkap tanggapan mahasiswa terhadap bahan ajar yang dikembangkan; b) Angket diberikan kepada subyek uji coba dengan kelompok yang lebih luas yang meliputi semua subyek penelitian. Angket ini berisi serangkaian pertanyaan/pernyataan untuk mengungkap tanggapan subyek terhadap bahan ajar yang dikembangkan serta kritik dan saransaran responden.

\section{Analisis Data}

Analisis data dilakukan melalui Analisis Hasil Wawancara dan Analisis Tanggapan mahasiswa Terhadap Bahan Ajar yang dapat dijelaskan sebagai berikut: a) Analisis Hasil Wawancara. Data hasil wawancara dianalisis secara deskriptif kualitatif untuk memberikan penjelasan secara rinci tentang kendala yang dialami mahasiswa dalam mempelajari bahan ajar serta pendapat mahasiswa tentang bahan ajar yang sedang dikembangkan; b) Analisis Tanggapan mahasiswa Terhadap Bahan Ajar. Pada analisis tahap ini, data diperoleh dari skor angket tanggapan mahasiswa terhadap bahan ajar yang diberikan. Analisis dilakukan dengan analisis deskriptif. Tanggapan mahasiswa terhadap bahan ajar diperoleh dengan menentukan prosentase sub variabel menurut persamaan berikut:

$$
\mathrm{Ps}=\frac{\mathrm{S}}{\mathrm{N}} \cdot 100 \%
$$

Ps $=$ prosentase sub variabel

$\mathrm{S}=$ jumlah nilai tiap sub variabel

$\mathrm{N}=$ jumlah skor maksimum

Kategori tanggapan mahasiswa tiap sub variabel adalah sebagai berikut:

Jika $0 \%$ < skor $\leq 20 \%$ tidak baik Jika $21 \%<$ skor $\leq 40 \%$ kurang baik Jika $41 \%<$ skor $\leq 60 \%$ cukup baik Jika $61 \%<$ skor $\leq 80 \%$ baik Jika $81 \%<$ skor $\leq 100 \%$ baik sekali

\section{SIMPULAN}

Berdasarkan analisis penelitian dapat disimpulkan bahwa:

1. Permasalahan para pekerja di Indonesia mengenai Keselamatan dan Kesehatan Kerja masih sangat terabaikan, sehingga dapat menimbulkan angka kecelakaan kerja yang signifikan. Sedangkan perusahaan jasa konstruksi tidak dapat terlepas dari tenaga kerja, karena tenaga kerja adalah faktor utama yang terlibat dalam proses pembangunan.

2. Kontribusi terbesar penyebab kasus kecelakaan kerja adalah berasal dari faktor kelalaian manusia yaitu sebesar $88 \%$. Sedangkan $10 \%$ lainnya adalah dari faktor ketidaklayakan property / asset / barang dan 2\% faktor lainnya.

3. Dengan adanya penerapan program Keselamatan dan Kesehatan Kerja untuk mengubah pola pikir para pekerja dan membangkitkan kesadaran dari dalam diri para pekerja bahwa pentingnya Keselamatan dan Kesehatan Kerja (K3). 
SARAN

Mengingat bahwa adanya bahaya potensi risiko kerja di bidang jasa konstruksi maka masyarakat supaya untuk senantiasa menerapkan program Keselamatan dan Kesehatan Kerja yang akan berpotensi untuk meningkatkan Produktivitas kerja bagi para pekerja.

\section{DAFTAR PUSTAKA}

2015. American Society of Safety Engineers. History. Retrieved September 8 , 2015, from The American Society of Safety Engineers.

Badan Pembinaan Konstruksi dan SDM Departemen Pekerjaan Umum. 2007. Sistem Manajemen Keselamatan dan Kesehatan Kerja (SMK3). Jakarta: Departemen PU.

Charless A.W. 1999. Kajian Kelengkapan dan Keselamatan Kerja Pada pekerja Kontruksi di Indonesia. LA Satriawan2009-ejournal eajy ac.id

Ervianto, Wulfram I. 2005. Manajemen Proyek Konstruksi. Yogyakarta: Andi Offset.

Handoko, Dwi. 2014. Pengaruh Keselamatan dan Kesehatan Kerja Pada Bangunan Pekerjaan Gedung dan Penataan Ruang. Jurnal Konstruksia. Volume 5 Nomor 2 Agustus 2014. Jakarta: Universitas Muhammadiyah Jakarta.
Heinrich, H.W., 1931. Industrial accident prevention. New York: Mc Graw hill book company.

International Labour Organization. 1998. Improving working conditions and productivity in the garment industry: Practical ideasfor owners and managers of small and medium-sized enterprises. Geneva: International Labour Office.

Peraturan Pemerintah No. 50 Tahun 2012. Tentang Sistem Manajemen Keselamatan dan Kesehatan Kerja (SMK3).

Ramlan, Djamaluddin. 2006. Dasardasar Keselamatan dan Kesehatan kerja Jilid I, Purwokerto: Universitas Soedirman.

Ramli, S. 2010. Sistem Manajemen Keselamatan dan Kesehatan Kerja, OHSAS 18001. Jakarta: Penerbit Dian Rakyat.

Siregar. 2005. Masalah Keselamatan dan Kesehatan Kerja :1. Malang: UIN Malang.

Sulaksmono, M. 1997. Manajemen Keselamatan Kerja. Surabaya: Penerbit Pustaka.

Suma'mur, P.K. 1989. Ergonomi untuk Produktivitas Kerja. Jakarta: CV. Haji Mas Agung.

Taugeha, Winda Purnama. 2018. Manajemen Risiko Keselamatan dan Kesehatan Kerja (K3) pada proyek Konstruksi. Jurnal Teknik Sipil Vol 6. No 11. 